\title{
MEMBUMIKAN PANCASILA ARTI PENTING MENEGAKKAN HAM SEBAGAI TAMENG TOLERANSI KEBERAGAMAN
}

\author{
Indra Wicaksono \\ Mahasiswa Fakultas Hukum, Universitas Ahmad Dahlan
}

Surel: indraissi12@gmail.com

\begin{abstract}
ABSTRAK
Pentingnya membumikan pancasila guna menegakkan HAM sebagai tameng toleransi keberagaman. Dengan mengetahui tentang intoleransi dapat melanggar HAM dan mengetahui peran sila-sila dalam pancasila guna menghadapi intoleransi keberagaman. Namun demikian tafsiran itu dijabarkan melalui pasal-pasal dalam peraturan perundang-undangan salah satunya seperti yang dinyatakan dalam pasal 28E UUD NRI 1945 dan didalam pasal 22 ayat (1) UU No. 39 Tahun 1999 tentang Hak Asasi Manusia. Jika hak yang dimaksud dalam pasal tersebut dirampas oleh orang lain maka yang akan terjadi adalah intoleransi keberagaman yang melanggar HAM. Sila dalam pancasila itu sendiri memiliki peran penting dalam menghadapi intoleransi ini. Lima sila pancasila tersebut merupakan wujud dari persatuan warga negara Indonesia atas perbedaannya.
\end{abstract}

RIWAYAT ARTIKEL

Article History

Diterima 17 Oktober 2018

Dipublikasi 20 November 2018

\section{KATA KUNCI}

Keywords

Intoleransi, Keberagaman,

Pancasila

HOW TO CITE (saran perujukan):

Wicaksono, I. (2018). "Membumikan Pancasila Arti Penting Menegakkan HAM Sebagai

Tameng Toleransi Keberagaman", Lex Scientia Law Review. Volume 2 No. 2, November, hlm. 169-176 


\section{PENDAHULUAN}

Lahirnya bangsa ini diawali dengan adanya kerajaan-kerajaan kuno di Indonesia (AECO, 2017). Kemudian sampai kepada datangnya bangsa-bangsa penjajah yang menguasai negeri ini. Bangsa Indonesia berjuang demi meraih kemerdekaan setelah sekian lama di jajah oleh bangsa lain dan merdeka pada tanggal 17 agustus 1945. Kemerdekaan Indonesia ditandai dengan adanya proklamasi yang diproklamatori oleh presiden pertama yaitu Ir. Soekarno. Setelah Indonesia merdeka bangsa ini masih memiliki perkerjaan yang berat dalam menyusun ketatanegaraan termasuk sebelumnya dalam merumuskan dasar negara yang melahirkan perdebatan panjang dimana hal itu dilatar belakangi dengan rumusan sila pancasila yang diajukan oleh beberapa tokoh bangsa Indonesia karena adanya faktor perbedaan agama, budaya dan ras di Indonesia dan pada akhirnya pada tanggal 18 juni 1945 terbentuklah rumusan final dasar negara bangsa Indonesia yang disebut Pancasila serta mengesahkan UUD Negara Kesatuan RI oleh PPKI (Al Marsudi, 2012:31). Pancasila pada hakikatnya mengandung dua pokok pengetian yakni sebagai Pandangan Hidup Bangsa Indonesia dan sebagai Dasar Negara Republik Indonesia (Al Marsudi, 2012:1). Pancasila merupakan dasar negara sekaligus sumber dari segala sumber hukum artinya pancasila merupakan dasar hukum tertinggi dalam peraturan perundang-undangan di Indonesia seperti yang terdapat dalam batang tubuh UUD NRI 1945 (pasal-pasal). Pancasila juga memiliki fugsi penting yakni pancasila sebagai pemersatu bangsa (AHA, 2017). Arti pemersatu disini bahwa pancasila merupakan media untuk mempersatukan seluruh rakyat Indonesia dengan segala perbedaannya (plural).

Penanaman nilai-nilai pancasila dalam kehidupan bernegara sangat penting melihat latar belakang bangsa Indonesia yang beragam agama, ras dan budaya. Pancasila sendiri memiliki 5 sila yakni : 1. Ketuhanan Yang Maha Esa; 2. Kemanusiaan yang adil dan beradab; 3. Persatuan Indonesia; 4. Kerakyatan yang dipimpin oleh hikmat kebijaksanaan dalam permusyaratan perwakilan; 5. Keadilan sosial bagi seluruh rakyat Indonesia. kelima sila tersebut memiliki arti, nilai dan fungsi masing-masing. Namun sayangnya keberadaan pancasila tidak sepenuhnya berjalan dengan baik, hal ini terjadi karena ada beberapa persoalan salah satunya yakni intolerasi keberagaman. Intoleransi itu sendiri merupakan niscaya pandangan dan sikap meremehkan keyakinan dan ibadah orang yang berbeda (Labib,2016). Mengenai intoleransi keberagaman di Indonesia masih terlihat bahkan ditahuntahun politik persoalan mengenai intoleransi semakin kompleks. Persoalan intoleransi saat ini lebih dominan kepada perbedaan keyakinan (agama). Sejak dahulu kelompok intoleransi sudah ada. Namun berbeda dengan sekarang, bahwa kelompok tersebut semakin berani melarang kegiatan kelompok kepercayaan yang berbeda (Taufiqurrohman, 2017).

https://journal.unnes.ac.id/sju/index.php/Islr/

Copyrights (c) 2018. UKM Lex Scientia, Fakultas Hukum Universitas Negeri Semarang 
Intoleransi juga tidak hanya merambat dalam ranah kepercayaan namun juga pada bidang lain. Seperti yang dinyatakan oleh Zuhairi (2008) mengatakan persoalan anti toleransi/intoleransi dan anti pluralisme yang semakin menguat tidak hanya dipengaruhi oleh iman dan kitab suci, tetapi banyak dipengaruhi oleh faktor riil, seperti politik, ekonomi, sosial dan budaya (Ginting.dkk, 2009) Jika intoleransi tumbuh di Indonesia maka hal ini tentu tidak sesuai dengan apa yang di cita-citakan oleh pancasila. Kehadiran intoleransi dalam ranah kehidupan bernegara di Indonesia pada akhirnya akan menuju kepada pelanggaran Hak Asasi Manusia (HAM). Oleh karena itu lahirnya pancasila yang terdiri dari 5 sila sangat penting dalam penerapan hidup bernegara dengan warga negara yang berbeda-beda.

Uraian diatas menunjukan bahwa lahirnya pancasila bukan berarti menghilangkan keberadaan intoleransi keberagaman dalam semua bidang terkusus perbedaan kepercayaan dimana intoleransi tersebut akan berdampak menimbulkan pelanggaran HAM. Dengan demikian penulis menulis karya tulis ilmiah ini dengan judul "MEMBUMIKAN PANCASILA ARTI PENTING MENEGAKAN HAM SEBAGAI TAMENG TOLERANSI KEBERAGAMAN".

\section{Rumusan Masalah}

1. Bagaimana intoleransi keberagaman dapat melanggar HAM?

2. Bagaimana peran sila-sila dalam pancasila guna menghadapi intoleransi keberagaman?

\section{Metode Penulisan}

Metode yang digunakan dalam penulisan jurnal ilmiah ini menggunakan metode yuridis normatif. Yuridis normatif itu sendiri merupakan metode penelitian yang difokuskan untuk mengkaji kaidah-kaidah atau norma-norma dalam hukum positif (peraturan perundang-undangan) (Ibrahim, 2006:295). Sumber bahan hukum penelitian ini terdiri dari Undang-Undang Dasar Negara Republik Indonesia Tahun 1945, Undang-Undang. Bahan hukum ini diambil melalui perpustakaan dan media internet. Seluruh bahan hukum tersebut kemudian dianalisis dengan analisis deskriptif untuk dapat menganalisis dengan tepat mengenai intoleransi keberagaman dapat melanggar HAM dan peran sila-sila dalam pancasila guna menghadapai intoleransi keberagaman. 


\section{PEMBAHASAN}

\section{A. Intoleransi Keberagaman Bentuk Pelanggaran HAM}

Intoleransi adalah tindakan memandang dengan sikap meremehkan keyakinan orang yang berbeda. Oleh karena itu hal ini lah yang kemudian memicu adanya pelanggaran HAM.

Indonesia merupakan negara hukum hal ini tertuang didalam Pasal 1 ayat (3) UUD NRI 1945. Dengan demikian segala sesuatu tindakan yang dilakukan baik oleh penguasa maupun warga negara harus berlandaskan dan memperhatikan hukum yang berlaku. Hal ini dilakukan supaya terciptanya kehidupan yang teratur dan tertib termasuk toleransi atau menghargai hak asasi manusia seperti perbedaan pendapat, kepercayaan, ras, budaya dan lain sebagainya. Kondisi Hak asasi manusia sudah diatur dalam konstitusi UUD NRI 1945 ayat 28A sampai 28J. Pasal tersebut antara lain berisikan mengenai hak untuk hidup, hak mendapat persamaan dan keadilan, berhak atas jaminan sosial, hak beragama, setiap orang wajib menghormati hak asasi manusa orang lain dan lain sebagainya. Adapun turunan dari Pasal 28 UUD NRI 1945 tersebut adalah UU No. 39 tahun 1999 tentang Hak Asasi Manusia dimana undang-undang ini mengatur HAM secara rinci. Termasuk dalam mengatur keberadaan Komnas HAM yang merupakan lembaga mandiri serta berfungsi melaksanakan pengkajian, penelitian, penyuluhan, pemantauan, dan mediasi hak asasi manusia juga diatur dalam UU HAM ini. Dengan demikian dengan adanya komnas HAM yang bekerja sama dengan pihak terkait diharapkan kasus ham terutama yang disebabkan oleh intoleransi keberagaman seperti budaya, ras dan terkhusus kepercayaan (agama) akan redup di Indonesia.

Namun dengan hadirnya komnas HAM, kasus intoleransi di Indonesia masih banyak terjadi. Setara Institute mencatat sepanjang tahun 2017 terjadi 151 peristiwa pelanggaran kebebasan keyakinan (agama) dengan 201 bentuk tindakan yang terjadi di 26 provinsi se-Indonesia (Nadlir, 2018). Data tersebut menunjukan bahwa intoleransi merupakan pekerjaan yang harus diselesaikan oleh pemerintah.

Intoleransi keberagaman dapat dikatakan melanggar HAM karena intoleransi itu sendiri merupakan tindakan yang tidak menerima akan perbedaan (agama, ras dan budaya) serta sikap sesorang dengan cara merendahkan sesorang yang lain karena adanya perbedaan. Padahal Pancasila yang merupakan pedoman hidup bernegara beserta peraturan perundang-undangan lainnya mengatur dan menjamin hak asasi manusia sesorang. Inilah yang kemudian intoleransi dapat melanggar HAM karena tindakannya mengganggu atau merampas hak asasi orang lain.

Ditinjau dari segi hukum yang berlaku melalui UUD NRI 1945 dan UU No. 39 tahun 1999 tentang HAM tafsiran larangan intoleransi itu sendiri tidak dijelaskan secara langsung dalam peraturan perundang-undang tersebut. Merujuk 
pada uraian diatas maka tafsiran mengenai larangan intoleransi ditinjau dari praturan perundang-undangan sangat luas seperti yang dinyatakan dalam Pasal 28E UUD NRI 1945 bahwa Setiap orang berhak memeluk agama dan beribadat menurut agamanya, memilih pendidikan dan pengajaran, memilih pekerjaan dan lain sebagainya. Maksud dari pasal tersebut adalah semua orang itu memiliki hak untuk memeluk agama dan hak lainnya yang tidak bisa diambil atau dirampas haknya dengan sewenang-wenang oleh orang lain. Kemudian hal yang sama dijabarkan lebih spesifik mengenai agama dalam UU tentang HAM Pasal 22 ayat (1) bahwa "Setiap orang bebas memeluk agamanya masing-masing dan untuk beribadat menurut agamanya dan kepercayaannya itu". Berdasarkan uraian tersebut maka hak sesorang dalam memeluk agamanya dikuatkan dan dijamin oleh negara.

Dengan demikian jika hak yang dimaksud dari uraian tersebut dirampas oleh orang lain karena adanya perbedaan keberagamaan seperti agama maka munculah yang disebut intoleransi. Oleh karena itu intoleransi merupakan salah satu bentuk pelaggaran HAM karena seseorang tidak bisa menerima akan perbedaan orang yang lain.

\section{B. Peran Sila-Sila Pancasila Dalam Menghadapi Intoleransi Keberagaman}

Pancasila merupakan dasar negara dan sumber dari segala sumber hukum. Dengan demikian pancasila merupakan sumber UUD NRI 1945 dan peraturan perundang-undangan lainnya. Pancasila memiliki lima sila yang terdiri dari : ketuhanan Yang Maha Esa; Kemanusiaan yang adil dan beradab; Persatuan Indonesia; Kerakyatan yang dipimpin oleh hikmat kebijaksanaan dalam permusyawaratan perwakilan; Keadilan sosial bagi seluruh rakyat Indonesia. kelima sila tersebut memiliki peran masing-masing termasuk dalam menghadapai persoalan intoleransi keberagaman.

Sila pertama pancasila yang berbunyi Ketuhanan Yang Maha Esa merupakan nilai-nilai mengenai kepercayaan/agama dimana pada sila ini negara Indonesia merupakan negara yang memiliki berbagai keyakinan seperti agama islam, katolik, kristen, hindu dan budha. Sila ini memberi pedoman bahwa dengan adanya perbedaan keyakinan itu maka kehidupan bernegara harus berdasarkan keyakinan dan saling menghargai kepercayaan masing-masing manusia. Tentu hal ini merupakan bagian pemersatu dengan adanya perbedaan agama/keyakinan.

Sila kedua pancasila yang berbunyi kemanusiaan yang adil dan beradab mengandung nilai-nilai kehidupan bernegara dimana seluruh rakyat Indonesia memiliki status, derajat, dan hak yang sama dengan didasari oleh adab (sopan santun). Oleh karena itu pada sila kedua ini mencangkup mengenai hak dan kewajiban warga negara seperti menjalankan hak-haknya serta berkewajiban untuk menhormati hak orang lain.

Selanjutnya dalam sila ketiga pancasila yang berbunyi persatuan Indonesia mengandung nilai-nilai kehidupan bernegara dimana kemajemukan rakyat Indonesia merupakan bentuk kesatuan. Sila ini juga memberi ruang bagi budaya 
yang plural artinya bahwa keberadaan budaya yang beragam di Indonesia dapat berdiri tanpa adanya gangguan dari pihak manapun termasuk gangguan tindakan yang tidak saling menghargai dalam budaya. Oleh karena itu nilai penting dalam persatuan Indonesia adalah solidaritas, jiwa bela negara yang tinggi serta menghargai keseimbangan antara kepentingan pribadi dan masyarakat (bp3ipjakarta.ac.id, 2018).

Kemudian sila keempat pancasila yang berbunyi kerakyatan yang di pimpin oleh hikmat dalam kebijaksanaan dalam permusyawaratan perwakilan memiliki makna demokrasi yang berarti bahwa kekuasaan tertinggi berada ditangan rakyat. Demokrasi dalam sila keempat ini mengandung nilai-nilai yaitu : a. Kebebasan yang disertai dengan tanggung jawab baik terhadap masyarakat bangsa maupun kepada Tuhan yang Maha Esa; b. Menjunjung tinggi harkat dan martabat manusia; c. Setiap warga negara Indonesia memiliki kedudukan, hak dan kewajiban yang sama; d. Tidak Boleh memaksakan kehendak kepada orang lain; e. Mengutamakan musyawarah dalam mengambil keputusan untuk kepentingan bersama; $\mathrm{f}$. Mengakui perbedaan dan persamaan sebagai individu, kelompok, ras, suku, agama (Yusdiyanto, 2016:266-267). Dengan demikian sila keempat ini tidak jauh berbeda dengan sila-sila pancasila yang lainnya.

Sila kelima merupakan sila terakhir dari pancasila yang berbunyi keadilan sosial bagi seluruh rakyat Indonesia. Sila kelima ini memiliki nilai- nilai bahwa warga negara termasuk pemerintah dalam menerapkan suatu keadilan harus menjunjung tinggi harkat dan martabat setiap manusia tanpa pengecualian. Merujuk pada uraian tersebut maka makna keadilan sosial mencakup pula pengertian adil dan makmur (Al Marsudi, 2012:61).

Pancasila yang merupakan dasar negara dan pedoman hidup bernegara perlu hadir sebagai pemersatu sebagaimana diketahui bahwa Indonesia merupakan negara yang memiliki perbedaan/kemajemukan agama, ras dan budaya. Sebagaimana yang sudah diuraiakan diatas mengenai nilai-nilai yang ada dalam pancasila bahwa pancasila menghendaki adanya perbedaan baik itu agama, ras maupun budaya. Dengan demikian pancasila merupakan wadah atau alat untuk mencegah adanya intoleransi keberagaman. Hal ini tentu juga membutuhkan dukungan dari warga negara beserta pemerintah untuk mewujudkan peranan nilainilai yang ada dalam lima sila pancasila kedalam kehidupan bernegara supaya terciptanya kehidupan yang tertib dan tentram sehingga intoleransi akan semakin meredup.

\section{KESIMPULAN}

Intoleransi merupakan tindakan sesorang yang tidak bisa menerima adanya perbedaan baik dalam hal agama, ras dan budaya. Intoleransi itu sendiri jika terjadi dapat mengarah kepada pelanggaran HAM. Tafsiran mengenai larangan intoleransi

https://journal.unnes.ac.id/sju/index.php/lsIr/

Copyrights (c) 2018. UKM Lex Scientia, Fakultas Hukum Universitas Negeri Semarang 
dalam UUD NRI 1945 dan UU No. 39 tahun 1999 tentang HAM tidak dijelaskan secara langsung oleh karena itu tafsiran tersebut menjadi sangat luas. Pasal 28E UUD NRI 1945 menyatakan bahwa setiap orang berhak memeluk agama dan beribadat menurut agamanya, memilih pendidikan dan pengajaran, memilih pekerjaan dan lain sebagainya. Sedangkan dalam Pasal 22 ayat (1) UU tentang HAM menyatakan bahwa setiap orang bebas memeluk agamanya masing-masing dan untuk beribadat menurut agamanya dan kepercayaannya. Merujuk pada uraian tersebut maka jika hak yang dimaksud dirampas oleh orang lain karena adanya perbedaan keberagamaan seperti agama dan budaya maka munculah yang disebut intoleransi yang melanggar HAM seseorang. Dengan demikian intoleransi merupakan salah satu bentuk pelaggaran HAM.

Pancasila dalam peraturan perundang-undangan merupakan sumber hukum tertinggi. Pancasila memiliki lima sila yakni : Ketuhanan Yang Maha Esa; Kemanusiaan yang adil dan beradab; Persatuan Indonesia; Kerakyatan yang dipimpin oleh hikmat kebijaksanaan dalam permusyawaratan perwakilan; Keadilan sosial bagi seluruh rakyat Indonesia. Lima sila tersebut memiliki peran penting masing-masing dalam kehidupan bernegara. Pancasila sebagai pandangan hidup bernegara menghendaki adanya perbedaan baik itu agama, ras maupun budaya oleh karena itu pancasila merupakan pedoman hidup dalam kemajemukan/pluralism. Merujuk pada uraian tersebut maka pancasila merupakan alat yang digunakan untuk mencegah adanya intoleransi keberagaman sehingga dengan berpedoman dari pancasila dapat memberikan semangat toleransi atas perbedaan menjadi satukesatuan. 


\section{DAFTAR PUSTAKA}

Buku

Al Marsudi, Subandi. (2012), Pancasila dan UUD'45 Dalam Paradigma Reformasi, Cet. 7, Jakarta: PT. RajaGrafindo Persada.

Ibrahim, Johnny. (2006), Teori dan Metodologi Penelitian Hukum Normatif, Malang:

Penerbit Bayumedia Publishing.

Jurnal

Yusdiyanto, Makna Filosofis Nilai-nilai Sila Ke-Empat Pancasila Dalam Sistem Demokrasi Di Indonesia, Fiat Justisia Journal of Law, Vol 10 Issue 2, 2016.

\section{Internet}

AECO, STIE, Pengertian landasan historis, kultural, yuridis, dan filosofis pendidikan

Pancasila, http://www.stieaeco.ac.id/wpcontent/uploads/2017/09/Pengertianlandasan-historis.pdf, Diunduh pada 12 Oktober 2018.

BlogWeb, AHA, Pancasila : Pengertian, Fungsi, Isi, Bunyi, Tujuan, http://www.ilmudasar.com/2017/07/Pengertian-Fungsi-Isi-Bunyi-danTujuan-Pancasila-adalah.html, Diunduh pada 12 Oktober 2018 .

Ginting, Rosalina \& Aryaningrum, Kiki, Toleransi dalam Masyarakat Plural, https://media.neliti.com/media/publications/146613-ID-toleransi-dalammasyarakat-plural.pdf, Diunduh pada 12 Oktober 2018.

Labib, Dr. Muhsin, Toleransi terhadap Intoleransi ?, https://seword.com/sosbud/toleransi-terhadap-intoleransi, Diunduh pada 14 Oktober 2018

Nadlir, Moh. Tahun 2017, Pelanggaran Kebebasan Beragama Terbanyak di JawaBara, nasional.kompas.com, https://nasional.kompas.com/read/2018/01/15/18233341/tahun-2017pelanggaran-kebebasan-beragama-terbanyak-di-jawa-barat, Diunduh pada 14 Oktober 2018.

Tanpa nama, Pendidikan Kewarganegaraan BAB IV, http://bp3ipjakarta.ac.id/attachments/article/609/PENDIDIKAN\%20KE WARGANEGARAAN\%20BAB\%20IV.pdf, Diunduh pada 15 Oktober 2018. 